\title{
Pengaruh Gaya Kepemimpinan Dan Kompensasi Terhadap Kinerja Karyawan PT. Sumber Bening Lestari
}

\author{
Alfiah ${ }^{1}$ \\ Program Studi Manjememen, STIE Kertanegara Malang \\ alfiah.said@gmail.com \\ Widi Astutik ${ }^{2}$ \\ Program Studi Manjememen, STIE Kertanegara Malang \\ widiastutik671@gmail.com
}

\begin{abstract}
PT Sumber Bening Lestari is an attractive bottled mineral water company for various community needs, the company is located in Pandaan, East Java. This study aims to examine and provide empirical evidence about the analysis of the influence of leadership style and compensation on employee performance at PT Sumber Bening Lestari. The research instrument used was a questionnaire distributed to 70 employees of the production department taken using purposive sampling techniques. Furthermore, the collected data was analyzed using statistical analysis, namely descriptive statistical analysis and inferential statistical analysis. The results of this study indicate the results of the study found that leadership style variables influence employee performance, compensation variables affect employee performance and simultaneously leadership style variables and compensation affect the performance of employees of PT Sumber Bening Lestari Pandaan.
\end{abstract}

Keywords: Leadership Style, Employee's Performance, PT Sumber Bening Lestari

\section{ABSTRAK}

PT Sumber Bening Lestari adalah perusahaan air mineral kemasan yang menarik untuk berbagai kebutuhan masyarakat, perusahaan ini berada di Pandaan Jawa Timur.

Penelitian ini bertujuan untuk menguji dan memberikan bukti empiris tentang analisis pengaruh gaya kepemimpinan dan kompensasi terhadap kinerja karyawan pada PT Sumber Bening Lestari. Instrumen penelitian yang digunakan adalah kuesioner yang disebarkan kepada 70 orang karyawan bagian produksi yang diambil dengan menggunakan teknik purpossive sampling. Selanjutnya, data yang telah terkumpul dianilisis menggunakan analisis statistic yakni analisis statistic deskriptif dan analisis statistic inferensial.

Hasil dari penelitian ini menunjukkan Hasil penelitian diketahui variabel gaya kepemimpinan berpengaruh terhadap kinerja karyawan, variabel kompensasi berpengaruh terhadap kinerja karyawan dan secara smultan variabel gaya kepemimpinan dan kompensasi berpengaruh terhadap kinerja karyawan PT Sumber Bening Lestari Pandaan.

Kata kunci: Gaya Kepemimpinan, Kinerja Karyawan, PT Sumber Bening Lestari 


\section{Pendahuluan}

Elemen penting bagi perusahaan dalam menjalankan usahanya tidak terlepas dari faktor sumber daya manusia. Faktor sumber daya manusia sudah dianggap tidak mumpuni dalam suatu perusahaan maka dapat dipastikan perusahaan akan mengalami penurunan kinerja perusahaan. Kinerja perusahaan adalah sejauh mana/tingkat keberhasilan perusahaan dalam mencapai tujuan tertentu dalam periode tertentu. Sedangkan kinerja karyawan merupakan tingkat pencapaian masing-masing karyawan dalam suatu perusahaan. Kinerja karyawan menjadi elemen terpenting dalam mencapai kinerja perusahaan yang memuaskan. Kinerja (Performance) mengacu kepada kadar pencapaian tugas-tugas yang membentuk sebuah pekerjaan karyawan. Kinerja merefleksikan seberapa baik karyawan memenuhi persyaratan sebuah pekerjaan (Simamora, 2015). Dari pengertian tersebut menjelaskan bahwa tingkat pencapaian karyawan dalam suatu perusahaan dapat diukur dari hasil pekerjaan yang telah dilakukannya dibandingkan dengan standar yang telah ditetapkan oleh perusahaan. Sehingga dapat diketahui karyawan tersebut mumpuni atau tidak.

Salah satu faktor yang mempengaruhi kinerja karyawan yaitu besar kompensasi (compensation) meliputi imbalan finansial dan jasa nirwujud serta tunjangan yang diterima oleh para karyawan sebagai dari hubungan kepegawaian. Kompensasi merupakan apa yang diterima oleh para karyawan sebagai ganti kontribusi mereka kepada organisasi (Simamora, 2015). Besarnya kompensasi mencerminkan status, pengakuan, dan tingkat pemenuhan kebutuhan yang dinikmati oleh karyawan bersama keluarganya (Hasibuan, 2017). Selain itu kinerja karyawan juga dipengaruhi oleh kepemimpinan yang dapat memotivasi, mengarahkan, dan memberi contoh kepada karyawan. Kepemimpinan merupakan faktor yang penting bagi sumber-sumber dan alat-alat suatu organisasi. Faktor-faktor yang berhubungan dengan sikap, gaya dan perilaku pemimpin sangat berpengaruh terhadap karyawan yang dipimpinnya bahkan turut berpengaruh terhadap kinerja organisasi.

Kepemimpinan (leadership) didefinisikan sebagai kemampuan untuk memengaruhi suatu kelompok guna mencapai sebuah visi atau serangkaian tujuan yang ditetapkan. Kepemimpinan merupakan kemampuan yang dipunyai seseorang untuk mempengaruhi orang-orang lain agar bekerja mencapai sasaran. Manajemen mencakup kepemimpinan, tetapi juga mencakup fungsi-fungsi lain seperti perencanaan, pengorganisasian dan pengawasan (Handoko, 2014).

Survey pendahuluan yang dilakukan pada karyawan PT. Sumber Bening Lestari diketahui bahwa masih terdapat karyawan yang kinerjanya kurang maksimal dikarenakan masih belum puas dengan kompensasi yang mereka terima masih kurangnya perhatian dari pimpinan dalam memberikan motivasi pada karyawan dalam bekerja. Alasan ini mendasari peneliti mengangkat judul penelitian Pengaruh Gaya Kepemimpinan Dan Kompensasi Terhadap Kinerja Karyawan PT. Sumber Bening Lestari.

\section{Metode Penelitian}

Jenis data yang digunakan dalam penelitian ini adalah data primer dan data sekunder. Sedangkan teknik pengumpulan data yang dilakukan dalam penelitian ini adalah metode angket yang menggunakan skala likert dari 1-5 dan observasi serta wawancara. Penelitian ini merupakan jenis penelitian deskriptif kuantitatif adalah penelitian yang dilakukan terhadap variabel mandiri, yaitu tanpa membuat perbandingan, atau menghubungkan dengan variabel lain (Sugiyono, 2017 :6) Penelitian ini bertujuan untuk menguji dan memberikan bukti empiris tentang analisis pengaruh gaya kepemimpinan dan kompensasi terhadap kinerja karyawan pada PT Sumber Bening Lestari. 
Penelitian yang menjadi variabel terikat (dependent variable) adalah Kinerja Karyawan (Y). Sedangkan variabel bebas (independent variable) adalah Gaya Kepemimpinan $\left(\mathrm{X}_{1}\right)$ dan Kompensasi $\left(\mathrm{X}_{2}\right)$.

Untuk lebih jelas tentang variabel, indikator dan item-item penelitian ini dapat dilihat pada tabel di bawah ini :

Tabel 1. Indikator dan Item Penelitian

\begin{tabular}{|c|c|c|c|}
\hline Konsep & Variabel & Indikator & Item-item \\
\hline $\begin{array}{l}\text { Manajemen } \\
\text { Sumber } \\
\text { daya } \\
\text { Manusia }\end{array}$ & $\begin{array}{l}\text { Gaya } \\
\text { Kepemimpinan } \\
\left(\mathrm{X}_{1}\right) \\
\text { Kompensasi }\left(\mathrm{X}_{2}\right)\end{array}$ & $\begin{array}{l}\text {-Energi dan } \\
\text { keteguhan hati } \\
\text {-Visi } \\
\text {-Menantang dan } \\
\text { mendorong } \\
\text {-Mengambil resiko } \\
\text {-Kesetiaan } \\
\text {-Harga diri } \\
\\
\text {-Gaji yang adil } \\
\text {-Insentif yang sesuai } \\
\text {-Tunjangan yang } \\
\text { sesuai } \\
\text {-Fasilitas yang } \\
\text { memadai }\end{array}$ & $\begin{array}{l}\text { Atasan yang pekerja keras } \\
\text { Kejelasan penyampaian visi } \\
\text { Menghargai kinerja secara } \\
\text { terbuka } \\
\text { Bersedia dengan resiko } \\
\text { kehilangan jabatan } \\
\text { Inspirasi dalam bekerja } \\
\text { Memberi semangat } \\
\text { Besarnya gaji yang diberikan } \\
\text { Kesesuaian insentif } \\
\text { Kesesuaian tunjangan } \\
\text { Ketersediaan fasilitas }\end{array}$ \\
\hline $\begin{array}{l}\text { Penilaian } \\
\text { Kinerja } \\
\text { Karyawan }\end{array}$ & $\begin{array}{l}\text { Kinerja karyawan } \\
(\mathrm{Y})\end{array}$ & Hasil kerja & $\begin{array}{l}\text { Kuantitas } \\
\text { Kualitas } \\
\text { Efisiensi } \\
\text { Standar } \\
\text { Pengetahuan } \\
\text { Ketepatan waktu }\end{array}$ \\
\hline
\end{tabular}

Sumber : Gitosudarmo dan Sudita (1997 : 211-214)

Populasi pada penelitian ini adalah 230 orang karyawan PT Sumber Bening Lestari, karena jumlah populasi lebih dari 100 orang, maka besarnya jumlah sampel ditentukan dengan rumus Slovin (Riduwan \& Kuncoro, 2014:52) sebagai berikut:

$\mathrm{n}=\frac{N}{N \cdot d^{2}+1}$

Dimana:

$\mathrm{n}=$ Jumlah sampel

$\mathrm{N}=$ Jumlah Populasi

$\mathrm{d}=$ Presesi/persen kelonggaran ketidaktelitian 
Berdasarkan rumus diatas, dengan presesi sebesar $10 \%$ maka diperoleh jumlah sampel sebagai berikut:

$$
\mathrm{n}=\frac{N}{N \cdot d^{2}+1}=\frac{230}{(230) \cdot(0,1)^{2}+1}=\frac{230}{3,30}=69,69 \text { dibulatkan = } 70 \text { Sampel }
$$

Teknik pengambilan sampel yang digunakan adalah purposive sampling yaitu penentuan sampel berdasarkan kriteria tertentu, adapun kriteria pemilihan sampel yaitu karyawan bagian produksi. Penelitian ini bertujuan untuk menguji dan memberikan bukti empiris tentang analisis pengaruh gaya kepemimpinan dan kompensasi terhadap kinerja karyawan pada PT Sumber Bening Lestari.

\section{Hasil dan Pembahasan}

\section{A. Uji Validitas}

Uji validitas ini dihitung dengan cara mengkorelasikan setiap skor item dengan total skor item dari setiap variabel yang diuji validitasnya. Jika nilai korelasi yang dihasilkan lebih besar dari niali $r$ tabel maka item-item dalam setiap variabel yang digunakan dalam penelitian dinyatakan valid.

Tabel 2. Hasil Pengujian Validitas

\begin{tabular}{|l|l|c|l|}
\hline Item & $\begin{array}{c}\text { Corrected } \\
\text { item total } \\
\text { correlation }\end{array}$ & $\begin{array}{c}r \text { tabel } \\
(\mathrm{N}=70 ; \alpha=0, \\
05)\end{array}$ & Keterangan \\
\hline X1 & 0.708 & 0.231 & Valid \\
X1 & 0.748 & 0.231 & Valid \\
X1 & 0.727 & 0.231 & Valid \\
X1 & 0.772 & 0.231 & Valid \\
X1 & 0.662 & 0.231 & Valid \\
X1 & 0.590 & 0.231 & Valid \\
\hline X2 & 0.792 & 0.231 & Valid \\
X2 & 0.829 & 0.231 & Valid \\
X2 & 0.899 & 0.231 & Valid \\
X2 & 0.876 & 0.231 & Valid \\
\hline Y & 0.885 & 0.231 & Valid \\
Y & 0.853 & 0.231 & Valid \\
Y & 0.909 & 0.231 & Valid \\
Y & 0.853 & 0.231 & Valid \\
Y & 0.866 & 0.231 & Valid \\
Y & 0.830 & 0.231 & Valid \\
\hline
\end{tabular}

Sumber : Lampiran SPSS Reliability

Tabel 2. menunjukkan bahwa nilai korelasi yang dihasilkan yang ditunjukkan oleh corrected item total correlation lebih besar dari nilai $r$ tabel maka dapat disimpulkan bahwa tiap-tiap item yang digunakan pada masing-masing variabel valid dan dapat digunakan untuk pengujian selanjutnya. 


\section{B. Uji Reliabilitas}

Pengujian reliabilitas dalam penelitian ini adalah dengan menggunakan rumus Cronbach's Alpha. Hasil pengujian reliabilitas untuk masing-masing variabel yang diringkas pada tabel 4.14 sebagai berikut:

Tabel 3. Hasil Pengujian Reliabilitas

\begin{tabular}{|l|l|l|}
\hline Variabel-variabel & Nilai Alpha & Keterangan \\
\hline Gaya Kepemimpinan (X1) & 0.789 & Reliabel \\
Kompensasi (X2) & 0.837 & Reliabel \\
Kinerja Karyawan (Y) & 0.813 & Reliabel \\
\hline
\end{tabular}

Sumber : Lampiran SPSS Reliability

Berdasarkan hasil pengujian reliabilitas diketahui nilai alpha untuk masing-masing variabel lebih besar dari 0,6 sehingga dapat disimpulkan pengukuran yang digunakan reliabel.

\section{Uji Normalitas}

Uji normalitas bertujuan untuk menguji apakah dalam model regresi, variabel pengganggu atau residual memiliki distribusi normal. Pendekatan yang digunakan untuk uji normalitas pada penelitian ini yaitu uji statistik non-parametrik Kolmogorov-Smirnov (K-S). Untuk menguji apa data berdistribusi normal atau tidak dilakukan uji statistik Kolmogorov-smirnov Test. Residual berdistribusi normal jika memiliki nilai signifikansi > 0.05 dan hipotesisnya:

Ho : Data residual berdistribusi normal

$\mathrm{Ha}$ : Data residual tidak berdistribusi normal.

Hasil perhitungan residual uji normalitas tampak sebagai berikut :

\section{Gambar 1. Grafik Hasil Uji Normalitas}

One-Sample Kolmogorov-Smirnov Test

\begin{tabular}{|c|c|c|}
\hline & & $\begin{array}{l}\text { Unstandardiz } \\
\text { ed Residual }\end{array}$ \\
\hline $\mathrm{N}$ & & 70 \\
\hline Normal Parameters ${ }^{a, b}$ & Mean & $-5,82742 \mathrm{E}-09$ \\
\hline & Std. Deviation & 2,3479607 \\
\hline Most Extreme & Absolute & ,126 \\
\hline Dif $f$ erences & Positive & ,076 \\
\hline & Negativ e &,- 126 \\
\hline Kolmogorov-Smirnov Z & & 1,050 \\
\hline Asy mp. Sig. (2-tailed) & & ,220 \\
\hline
\end{tabular}

a. Test distribution is Normal.

b. Calculated from data.

Sumber : Data di olah dengan SPSS 22

Dari hasil perhitungan di atas diketahui besarnya nilai Kolmogorov-Smirnov 1.050 pada tingkat signifikan 0.220 yang artinya Ho diterima yang berarti data residual terdistribusi dengan normal. 


\section{Uji Heterokedastistas}

Uji Heterokedastisitas bertujuan menguji apakah dalam model regresi terjadi ketidaksamaan variance dari residual satu pengamatan ke pengamatan yang lain. Menurut Ghozali (2015:72) pendeteksian dengan menggunakan grafik plot dengan dasar analisis:

1. Jika ada pola tertentu, seperti titik-titik yang ada membentuk pola tertentu teratur maka mengindikasikan telah terjadi heterokedastisitas.

2. Jika tidak ada pola jelas serta titik-titik menyebar di atas dan di bawah angka 0 sumbu y maka tidak terjadi heterokedastisitas.

\section{Gambar 2. Pendeteksian Heterokedastisitas}

\section{Scatterplot}

Dependent Variable: $Y$

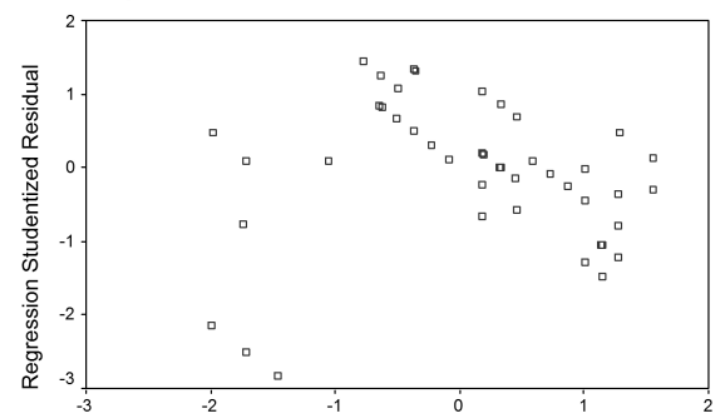

Regression Standardized Predicted Value

Sumber : Data di olah dengan SPSS 22

Dalam scaterplot di atas menunjukkan bahwa titik-titik menyebar tidak beraturan dan tidak membentuk suatu pola, sehingga dapat dikatakan model regresi yang diajukan terhindar dari heteroskedastisitas.

\section{E. Uji Multikolonieritas}

Tabel 4. Hasil Pengujian Multikolonieritas

\begin{tabular}{|l|c|l|}
\hline \multicolumn{1}{|c|}{ Variabel-Variabel } & VIF & \multicolumn{2}{|c|}{ Keterangan } \\
\hline Gaya Kepemimpinan $\left(\mathrm{X}_{1}\right)$ & 1.038 & Karena nilai variabel bebas $<10$, \\
Kompensasi $\left(\mathrm{X}_{2}\right)$ & 1.038 & $\begin{array}{l}\text { berarti tidak terdapat } \\
\text { multikolinearitas }\end{array}$ \\
\hline
\end{tabular}

Sumber : Data di olah dengan SPSS 22

Dari hasil pengujian multikolinieritas seperti yang tercantum pada tabel di atas dapat diketahui besarnya nilai VIF untuk masing-masing variabel bebas kurang dari 10 sehingga bisa Diduga bahwa antara variabel independen tidak terjadi persoalan multikolinieritas. 


\section{1) Uji Linear Berganda}

Hasil pengujian regresi berganda dapat diketahui nilai koefisien regresi masingmasing variabel bebas yang menunjukkan besarnya pengaruh dari tiap variabel bebas terhadap variabel terikat. Dimana variabel bebas dengan koefisien regresi terbesar adalah variabel bebas dengan pengaruh dominan. Adapun keseluruhan hasil regresi linier berganda sebagai berikut :

Tabel 5. Hasil Pengujian Regresi Berganda

Coefficients

\begin{tabular}{|c|c|c|c|c|c|c|c|c|}
\hline \multirow{2}{*}{\multicolumn{2}{|c|}{ Model }} & \multicolumn{2}{|c|}{$\begin{array}{l}\text { Unstandardized } \\
\text { Coeff icients }\end{array}$} & \multirow{2}{*}{$\begin{array}{c}\begin{array}{c}\text { Standardi } \\
\text { zed }\end{array} \\
\begin{array}{c}\text { Coeff icien } \\
\text { ts }\end{array} \\
\text { Beta } \\
\end{array}$} & \multirow[b]{2}{*}{$t$} & \multirow[b]{2}{*}{ Sig. } & \multicolumn{2}{|c|}{ Collinearity Statistics } \\
\hline & & $\mathrm{B}$ & Std. Error & & & & Tolerance & VIF \\
\hline & (Constant) & 1,919 & 2,568 & & ,747 & ,458 & & \\
\hline & $\mathrm{X} 1$ & ,421 & ,111 & ,289 & 3,793 & ,000 & ,963 & 1,038 \\
\hline & $\mathrm{X} 2$ & ,824 & 092 & ,682 & 8,944 &, 000 & ,963 & 1,038 \\
\hline
\end{tabular}

a. Dependent Variable: $Y$

Sumber : Data di olah dengan SPSS 22

$$
\begin{array}{ll}
\mathrm{X} 1 & =\text { Gaya Kepemimpinan } \\
\mathrm{X} 2 & =\text { Kompensasi } \\
\mathrm{Y} & =\text { Kinerja Karyawan }
\end{array}
$$

Dari perhitungan di atas dapat buat persamaan garis regresi untuk penelitian ini yaitu :

$$
\text { Kinerja Karyawan }=1.919+0.421 \times 1+0.824 \times 2+e
$$

Berikut ini akan dijelaskan pengaruh dari masing-masing variabel bebas seperti yang tercantum pada tabel di atas yaitu:

a. Nilai konstanta $(\mathrm{a})=1.919$

Nilai Konstanta (a) positif menunjukkan jika tidak ada variabel-variabel bebas berupa gaya kepemimpinan dan kompensasi yang mempengaruhi kinerja karyawan.

b. Variabel Gaya Kepemimpinan

Koefisien regresi variabel gaya kepemimpinan $\left(b_{1}\right)$ bernilai positif menunjukkan pengaruh yang searah antara variabel gaya kepemimpinan searah dengan variabel kinerja karyawan, berarti apabila gaya kepemimpinan meningkat maka akan meningkatkan kinerja karyawan.

c. Variabel Kompensasi

Koefisien regresi variabel kompensasi $\left(b_{2}\right)$ bernilai positif menunjukkan pengaruh yang searah antara variabel kompensasi searah dengan variabel kinerja karyawan, artinya jika kompensasi pada karyawan ditingkatkan maka akan meningkatkan kinerja karyawan.

d. Error term (e)

Error term $(e)=2.38$ artinya setiap peningkatan (penambahan) akan kinerja karyawan, selain dipengaruhi oleh kecenderungan meningkat atau menurunnya 
variabel gaya kepemimpinan dan kompensasi ternyata dipengaruhi oleh variabel lain yang ikut mempengaruhi kinerja karyawan sebesar 2.38. Variabel lain yang dimaksudkan adalah variabel lain yang belum dibahas dalam penelitian ini.

\section{2) Uji F}

Tabel 6. Hasil Pengujian Antara Variabel Bebas Dengan Variabel Terikatnya

\section{ANOVA}

\begin{tabular}{|c|c|c|c|c|c|c|}
\hline Model & & $\begin{array}{l}\text { Sum of } \\
\text { Squares }\end{array}$ & $\mathrm{df}$ & Mean Square & $\mathrm{F}$ & Sig. \\
\hline \multirow[t]{3}{*}{1} & Regression & 632,594 & 2 & 316,297 & 55,711 &, $000^{\mathrm{a}}$ \\
\hline & Residual & 380,391 & 67 & 5,677 & & \\
\hline & Total & 1012,986 & 69 & & & \\
\hline
\end{tabular}

a. Predictors: (Constant), X2, X1

b. Dependent Variable: $Y$

Sumber : Data di olah dengan SPSS 22

\section{Gambar 3. Kurva Uji F}

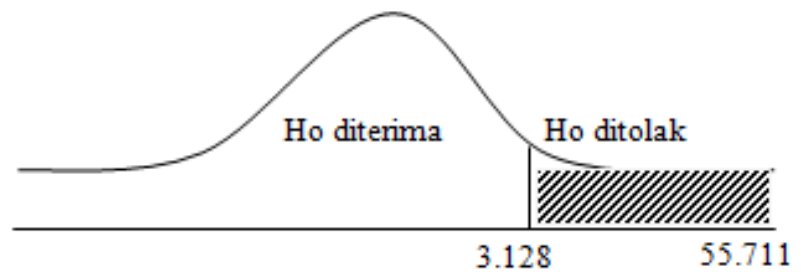

Sumber : Data di olah dengan SPSS 22

Hal ini berarti variabel-variabel gaya kepemimpinan (X1) dan kompensasi (X2) secara bersama-sama mempunyai pengaruh yang signifikan terhadap kinerja karyawan $(\mathrm{Y})$.

3) Uji T

- Variabel Gaya Kepemimpinan $\left(\mathrm{X}_{1}\right)$

\section{Gambar 4.Kurva Uji Parsial $\mathrm{X}_{1}$ terhadap $\mathrm{Y}$}

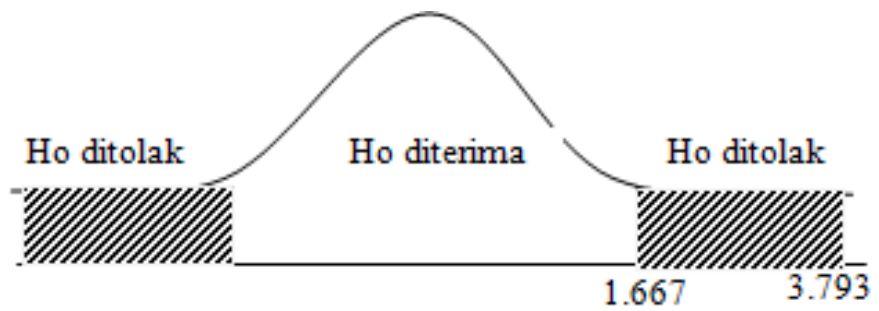

Sumber : Data di olah dengan SPSS 22 
Hasil grafik menunjukkan nilai t hitung berada di daerah menolak Ho sehingga diketahui variabel gaya kepemimpinan (X1) mempunyai pengaruh positif dan signifikan terhadap kinerja karyawan $(\mathrm{Y})$.

- Variabel Kompensasi (X2)

\section{Gambar 5. Kurva Uji Parsial X2 terhadap Y}

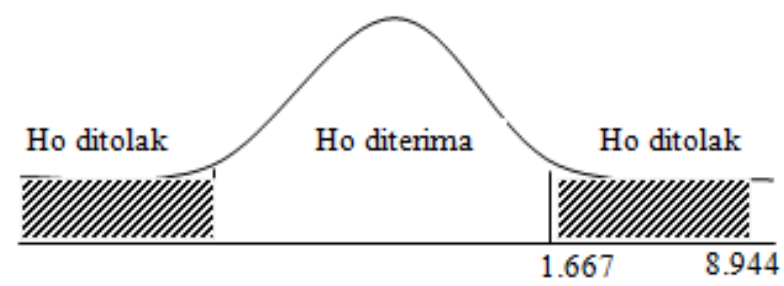

Sumber : Data di olah dengan SPSS 22

Hasil grafik menunjukkan nilai t hitung berada di daerah menolak Ho sehingga diketahaui variabel kompensasi (X2) mempunyai pengaruh positif dan signifikan terhadap kinerja karyawan (Y).

- Koefisien Determinasi atau R2

\section{Tabel 7. Uji Determinasi R}

Model Summary
\begin{tabular}{|l|r|r|r|r|c|}
\hline Model & \multicolumn{1}{|c|}{ R } & R Square & $\begin{array}{c}\text { Adjusted } \\
\text { R Square }\end{array}$ & $\begin{array}{c}\text { Std. Error of } \\
\text { the Estimate }\end{array}$ & $\begin{array}{c}\text { Durbin-W } \\
\text { atson }\end{array}$ \\
\hline 1 &, $790^{\text {a }}$ &, 624 &, 613 & 2,38 & 1,939 \\
\hline
\end{tabular}

a. Predictors: (Constant), X2, X1

b. Dependent Variable: $Y$

Sumber : Data di olah dengan SPSS 22

Besarnya nilai R Square di angka 0.624 atau $62.4 \%$ yang diperoleh menunjukkan besarnya kontribusi variabel-variabel bebas dalam penelitian terhadap variabel terikat. Hasil analisis diperoleh nilai $\mathrm{R}$ Square sebesar 0,624 yang berarti variabel-variabel gaya kepemimpinan (X1) dan kompensasi (X2) sebesar $62.4 \%$ yang artinya kemampuan variabel gaya kepemimpinan $(X 1)$ dan variabel kompensasi $(X 2)$ menjelaskan perubahan variabel kinerja karyawan $(Y)$ sebesar $62.4 \%$ sedangkan sisanya $37.6 \%$ dipengaruh oleh variabel lain yang tidak diteliti.

\section{PEMBAHASAN}

\section{A. Pengaruh gaya kepemimpinan dan kompensasi terhadap Kinerja Karyawan}

Dari hasil pengujian yang telah dilakukan bahwa diketahui secara bersama-sama (simultan) variabel gaya kepemimpinan dan kompensasi memiliki pengaruh yang 
signifikan terhadap kinerja karyawan. Hasil penelitian ini mengandung makna semakin tinggi gaya kepemimpinan dan kompensasi akan meningkatkan kinerja karyawan pada PT Sumber Bening Lestari Pandaan yang artinya gaya kepemimpinan yang diterapkan dan besarnya kompensasi yang diberikan perusahaan telah diterima oleh karyawan dengan baik. Hasil penelitian ini di dukung oleh hasil penelitian dari Johannes (2016) bahwa variabel gaya kepemimpinan dan kompensasi berpengaruh secara simultan terhadap kinerja karyawan.

\section{B. Pengaruh Gaya Kepemimpinan terhadap Kinerja Karyawan}

Hasil penelitian secara parsial diketahui variabel gaya kepemimpinan (X1) mempunyai pengaruh yang terhadap kinerja karyawan( $\mathrm{Y})$. Hasil penelitian ini mengandung makna gaya kepemimpinan yang telah diterapkan atasan perusahaan PT Sumber Bening Lestari Pandaan dengan indikator berupa atasan yang pekerja keras, kejelasan penyampaian visi, menghargai kinerja secara terbuka, bersedia dengan resiko kehilangan jabatan, inspirasi karyawan dalam bekerja dan memberi semangat kepada karyawan ternyata mampu meningkatkan kinerja karyawan. Hasil penelitian ini sejalan dengan penelitian yang dilakukan oleh Riyadi (2011) dan Johannes (2016) yang menyebutkan bahwa gaya kepemimpinan berpengaruh secara parsial terhadap kinerja karyawan.

\section{Pengaruh Kompensasi terhadap Kinerja Karyawan}

Variabel kompensasi (X2) pada penelitian ini diketahui mempunyai pengaruh yang positif terhadap kinerja karyawan pada PT Sumber Bening Lestari Pandaan. Hasil penelitian bermakna bahwa berbagai kompensasi yang telah diberikan perusahaan telah mampu memberikan pengaruh terhadap peningkatan kinerja karyawan. Berbagai macam kompensasi yang ada di perusahaan diantaranya gaji, insentif, tunjuangan dan fasilitas mempengaruhi karyawa dalam bekerja. Hasil penelitian ini sejalan dengan penelitian yang dilakukan oleh Johannes (2016) dimana kompensasi berpengaruh terhadap kinerja karyawan. Dapat disimpulkan bahwa variabel kompensasi yang mempunyai indikator terdiri dari besarnya gaji, kesesuaian insentif, kesesuaian tunjangan dan ketersediaan fasilitas kerja mampu memberikan pengaruh positif terhadap kinerja karyawan pada PT Sumber Bening Lestari Pandaan.

\section{Kesimpulan}

Penelitian ini bertujuan untuk mengetahui pengaruh gaya kepemimpinan dan kompensasi terhadap kinerja karyawan PT Sumber Bening Lestari Pandaan dan untuk mengetahui variabel apa yang paling berpengaruh. Dari rumusan masalah penelitian yang diajukan, berdasarkan analisis data yang telah dilakukan, dan pembahasan yang telah dikemukakan, maka diperoleh kesimpulan sebagai berikut:

A. Hasil penelitian diketahui variabel gaya kepemimpinan berpengaruh terhadap kinerja karyawan PT. Sumber Bening Lestari Pandaan.

B. Hasil penelitian diketahui variabel kompensasi berpengaruh terhadap kinerja karyawan PT. Sumber Bening Lestari Pandaan.

Hasil penelitian secara smultan variabel gaya kepemimpinan dan kompensasi berpengaruh terhadap kinerja karyawan. 


\section{Saran}

Berdasarkan hasil penelitian ini, dapat disampaikan saran-saran sebagai berikut :

A. Bagi peneliti selanjutnya agar lebih menambah variabel-variabel yang diteliti dikarenakan variabel gaya kepemimpinan dan kompensasi pada penelitian ini hanya memberikan pengaruh sebesar $62.4 \%$ dan sisanya dipengaruhi oleh variabel lain yang tidak diteliti. Variabel yang bisa ditambahkan antara lain variabel motivasi dalam model penelitian selanjutnya.

B. Diharapkan PT Sumber Bening Lestari Pandaan untuk lebih meningkatkan kompensasi yang diberikan kepada karyawan. Hal ini dikarenakan kompensasi mempunyai pengaruh sangat dominan mempengaruhi kinerja karyawan. Bentuk kompensasi yang diberikan bisa berupa kenaikan gaji, peningkatan insentif, kenaikan tunjangan dan selalu menyediakan fasilitas kerja yang lebih baik.

\section{Daftar Pustaka}

Ashari, Muhammad., Apriatni EP., and Bulan Prabawani. 2014. The Effect Of Training and Work Motivation To Employee Performance PT. Nasmoco Pemuda Semarang. Diponegoro Journal Of Social And Politic. pp: 1-10.

Brahmasari, Ida Ayu dan Suprayetno,Agus. 2008. Pengaruh Motivasi Kerja, Kepemimpinan dan Budaya Organisasi Terhadap Kepuasan Kerja Karyawan serta Dampaknya pada Kinerja Perusahaan (Studi Kasus pada PT. Pei Hai International Wiratama Indonesia). Jurnal Manajemen dan Kewirausahaan, 10(2): pp: 124-135.

Handoko, T. Hani. 2012. Manajemen Personalia dan Sumber Daya Manusia. Yogyakarta: BPFE.

Hartantio, Widagdo Widi. 2013. Pengaruh Motivasi, Komunikasi Dan Lingkungan Kerja Terhadap Kinerja Karyawan Pada Sltp Ibu Kartini Semarang. Skripsi. Fakultas Ekonomi dan Bisnis Universitas Dian Nuswantoro Semarang.

Ismi Nabila, Sri Suryoko dan Sari Listyorini. 2013. Pengaruh Lingkungan Kerja, Kemampuan Kerja, dan Kompensasi Terhadap Kinerja Karyawan Bagian Produksi PT. Muria Jaya Kudus. Diponegoro Of Journal Social and Politic. 1(2): h: 1-8.

Jhon Ady Sarigih. 2009. Analisis Faktor-Faktor Yang Mempengaruhi Kinerja Karyawan PTPN III PKS Rambutan T. Tinggi. Thesis. Universitas Sumatera Utara.

Koh, W.L., Steers, R.M., and Terborg, J.R. 1995. The Effect of Transformational Leadership on Teacher Attitudes and Student Performance in Singapore. Journal of Organizational Behavior, 16: pp: 319-333.

Kristiawan, Dody., Suprayitno. 2009. Pengaruh Motivasi Dan Lingkungan Kerja Terhadap Kinerja Karyawan Dengan Kepemimpinan Sebagai Variabel Moderating. Jurnal Manajemen Sumberdaya Manusia. 3(2): h:115-121. 
Larissa and Parker, R. J. 2008. Antecendents of Budget Participation: Leadership Style, Information Asymmetry, and Evaluative Use of Budget. A Journal Of Accounting, Finance and Business, 44(4): pp: 457-489.

Mahmun, M Thoha. 2011. Pengaruh Disiplin Dan Kompensasi Terhadap Kinerja Pegawai Unit Pelaksana Teknis (UPT) Perpustakaan Universitas Sriwijaya. Jurnal Manajemen Sumberdaya Manusia. 2(3): h:1-12.

Mariam, Rani. 2009. Pengaruh Gaya Kepemimpinan Dan Budaya Organisasi Terhadap Kinerja Karyawan Melalui Kepuasan Kerja Karyawan Sebagai Variabel Intervening Studi Pada Kantor Pusat PT.Asuransi Jasa Indonesia (Persero). Tesis. Program Studi Magister Manajemen Program Pasca Sarjana Universitas Diponogoro, Semarang.

Masrukhin dan Waridin. 2006. Pengaruh Motivasi Kerja, Kepuasan Kerja, Budaya Organisasi dan Kepemimpinan terhadap Kinerja Pegawai. Jurnal EKOBIS 7(2): pp: 197-209.

Nawawi, H. 2009. Manajemen Sumber Daya Manusia untuk Bisnis yang Kompetitif.Yogyakarta : Gajah Mada University Press.

Nurcahyo, Anton. 2011. Analisis Variabel-Variabel Yang Memengaruhi Kinerja Karyawan Pada PT. Quadra Mitra Perkasa Balikpapan. Jurnal Eksis, 7(2): h:1972-1982.

Obasan, Kehinde A. 2012. Effect of Compensation Strategy on Corporate Perfomance: Evidence from Nigerian Firms. Research Journal of Finance and Accounting. 3(7): pp: 37-44.

Prayatna, Agus Heri dan Made Subudi. 2016. Pengaruh Gaya Kepemimpinan Terhadap Stres Kerja dan Kepuasan Kerja Karyawan Pada Fave Hotel Seminyak. E-Jurnal Manajemen Unud, 5(2): pp: 845-872.

Rahayu, V.T., Ariyani V., dan Kurniawan, S. 2013. Pengaruh Kepemimpinan Lingkungan Kerja Fisik, dan Kompensasi terhadap kinerja karyawan di PT. PLN Cabang Madiun. Jurnal Riset Manajemen Akuntansi Fakultas Ekonomi Universitas Widya Mandala Madiun, 1(1): h: 89-95.

Reza, Regina Aditya. 2010. Pengaruh Gaya Kepemimpinan, Motivasi dan Displin Kerja Terhadap Kinerja Karyawan PT. Sinar Santosa Perkasa. Skripsi. Program Sarjana Universitas Diponegoro Banjarnegara.

Robbins, Dan Coulter, Mary. 2010. Manajemen Edisi Kesepuluh. Jakarta: Penerbit Erlangga.

Saraswati, Yosiana Desi. 2014. Preferensi Faktor - Faktor Kinerja Karyawan Pada Perusahaan Daerah Air Minum (Pdam) Kabupaten Demak. Skripsi. Fakultas Ekonomika dan Bisnis Universitas Diponegoro.

Siwantara, I wayan. 2009. Pengaruh Kompetensi Profesional, Dan Motivasi Kerja Serta Iklim Organisasi Terhadap Disiplin Kerja Dan Kinerja Dosen Politeknik Negeri Bali. Jurnal Ragam. 9(2): h:224-241.

Sukmawati, Ferina. 2006. Pengaruh Kepemimpinan, Lingkungan Kerja Fisik dan Kompensasi terhadap Kinerja Karyawan di PT. Pertamina (Persero) UPMS III Terminal Transit Utama Balongan, Indramayu. Jurnal Ekonomi dan Bisnis. 2(3): h:175-194. 
Sutrisno, Edy. 2009. Manajemen Sumber Daya Manusia. Jakarta : Kencana. Syah, Harits. 2013. Pengaruh Kompensasi Finansial Terhadap Kepuasan Kerja Karyawan Dan Motivasi Kerja Karyawan Pada PT. Graha Raja Empat. Jurnal Ilmu Manajemen,1(2): h: 462-471.

Tahir, Satria. 2013. Analisis Kinerja Karyawan Pada Pt. Sinar Galesong Pratama (Sgp) Cabang Gorontalo. Publikasi Ilmiah. Fakultas Ekonomi dan Bisnis Universitas Negeri Gorontalo.

Umar, G. 2010.The Influence of Compensation on Performance of Sales Representatives of Pharmaceutical Companies Based in Ilorin - Nigeria.An International Multi-Disciplinary Journal, Ethiopia. 4(3b): pp: 223-239.

Usnul Khotimah. 2013. Pengaruh Gaya Kepemimpinan Transformasional dan Disiplin Terhadap Kinerja Karyawan Tetap Pada PT. Sari Lembah Subur Pelalawan. Skipsi. Universitas Riau.

Voon, M.L., M.C Lo K.S Ngui, and N.B. Ayob. 2012. The Influence Of Leadership Styles On Employees' Job Satisfaction In Public Sector Organizations In Malaysia. International Journal of Business, Management and Social Sciences, 2(1): pp : 24-32.

Widyatmini dan Lukman Hakim. 2008. Hubungan Kepemimpinan, Kompensasi dan Kompetensi Terhadap Kinerja Pegawai Dinas Kesehatan Depok. Skripsi. Universitas Gunadarma.

Wirawan, Nata. 2014. Cara Mudah Memahami Statistika Ekonomi dan Bisnis (Statistika Inferensi) Edisi ketiga. Denpasar: Keraras Emas.

Yensy, Nurul Astuty. 2010. Pengaruh Kompensasi dan Motivasi terhadap kinerja Guru Di SMA Negeri 2 Argamakmur Bengkulu Utara. Jurnal Kependidikan Triadik, 13(1): h: 34-42 